\title{
The Effect of Knowledge Components on the Inequality of Global Wealth Distribution
}

\author{
Abolfazl Shahabadi ${ }^{1}$ \\ Mina Kheshtmal Nasrani ${ }^{2}$ \\ Ali Moradi ${ }^{3}$
}

a.shahabadi@alzahra.ac.ir

\begin{abstract}
Inequality in global wealth distribution has led to a growing gap between developing and developed countries with regards to income levels, consumption rates, and living standards. In view of that, the difference between these two groups of countries in terms of levels of knowledge and technology infrastructure, human capital, and innovation-based production has been cited as the main reason for inequality in the distribution of global wealth. The present study examines the effect of knowledge components on the inequality of global wealth distribution in the selected leading countries in science, implementing the approach of panel data and the use of generalized moment method for the period 2010-2017. The estimated results demonstrate that the effect of components of economic incentives, institutional regimes, and information and communication technology infrastructure on the inequality of global wealth distribution for the selected countries is negative and significant. Nonetheless, the effect of components of the innovation system, education, and development of human resources on the inequality of global wealth distribution is positive and significant. In addition, the effect of control variables, such as main globalization index and economic globalization, on the inequality of global wealth distribution for the selected countries is positive and significant; Also, the effect of social globalization and political globalization on the inequality of global wealth distribution is not significant.
\end{abstract}

Keywords: Wealth Inequality, Knowledge Components, Economic Globalization, Social Globalization, Political Globalization.

JEL Classification: D31, D83, F60.

\footnotetext{
1. Professor, Department of Economics, Faculty of Social Science and Economics, Alzahra University, Tehran, Iran (Author Corresponding).

2. M.A Student in Business Management, Islamic Azad University, Branch Electronic, Tehran, Iran.

3. M.A in Economics, Islamic Azad University, Branch Arak, Iran.
} 


\section{تاثير مولفههاى دانش بر نابر ابرى توزيع ثروت جهانى}

a.shahabadi@alzahra.ac.ir ।

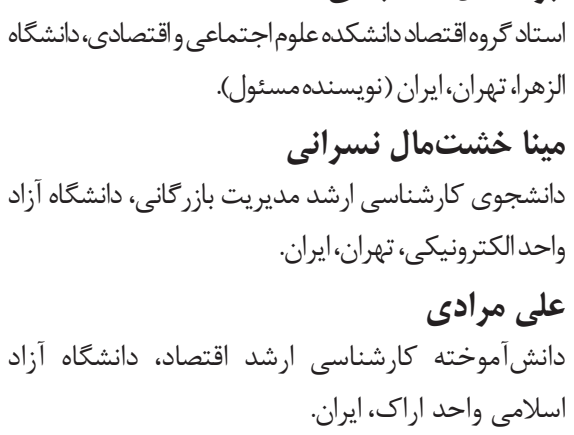

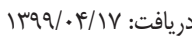

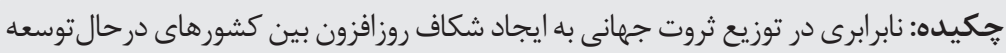

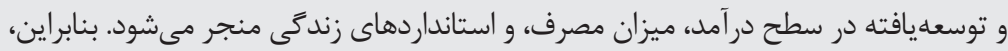

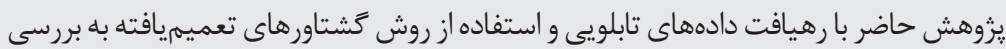

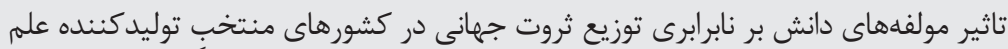

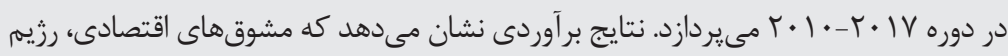

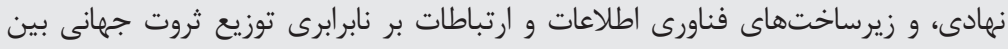

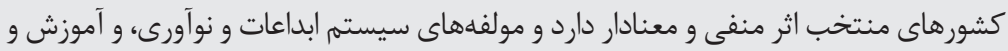

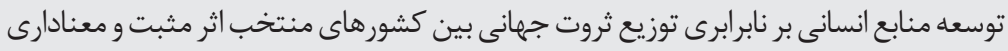

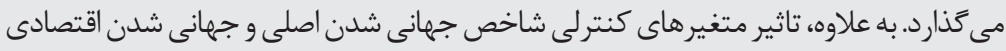

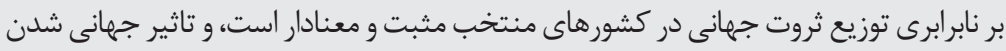

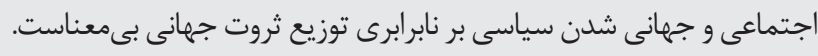

$$
\text { اجتماعى و جهانى شدن سياسى بر نابرابرى توزيع ثروت جهانى بىمعناست. }
$$


مقاله

امروزه، روند ميانگين ثروت سرانه در جهان در حال افزايش است، ولى نابرابرى در توزيع آن نيز

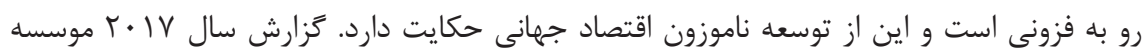

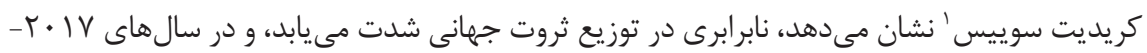

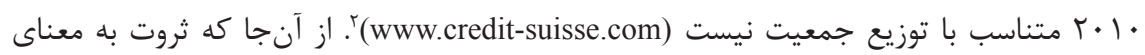

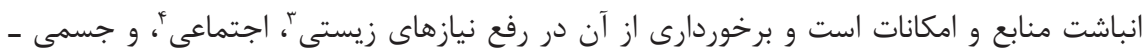

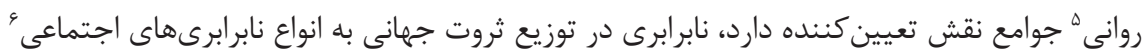

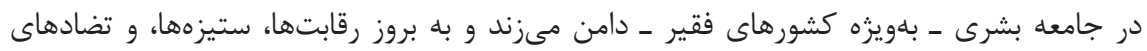

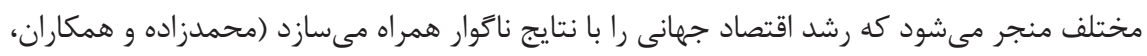

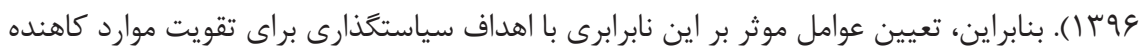

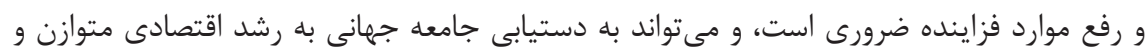
متعادل كمك نمايد. از سويى، امروزه رسيدن به رشد و توسعه اقتصادى، و افزايش ثروت ملّى صرفاً با اتكاى بر

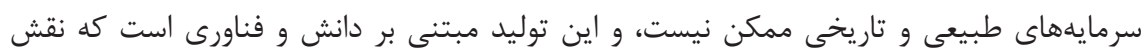

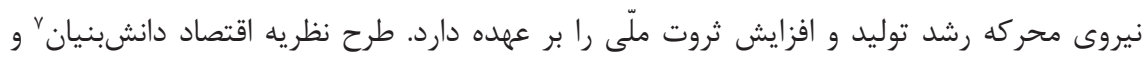
تبديل آن به بحث غالب در نظريههاى رشد و توسعه اقتصادى نيز در همين راستاست. از اينرو، توليد

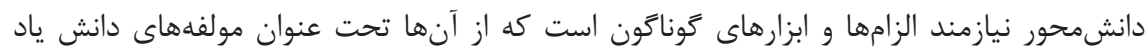
مىشود و شواهد تجربى نشان مى دهد كه كشورهاى درحال توسعه با برخوردارى كمتر از ثروت جهانى،

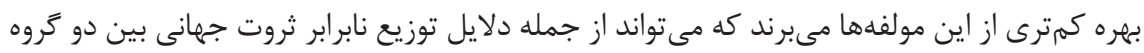

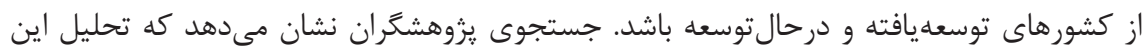

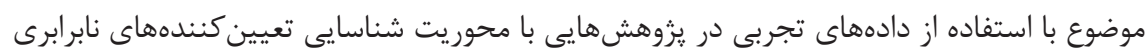

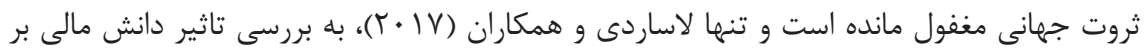

1. Credit Suisse

2. https://www.credit-suisse.com/articles/news-and-expertise/201711//en/global-wealth-report2017.html

3. Biological Needs

4. Social Needs

5. Psycho-Physical Needs

6. Social Inequality

7. Knowledge Based Economy 
نابرابرى ثروت در درون ايالات متحده آمريكا ـ نه در جامعه جهانى ـ يرداختهاند، كه از نظر موضوعى دانى

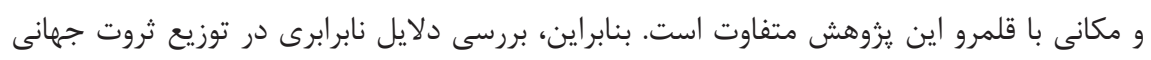

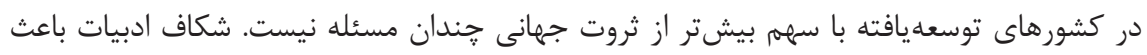

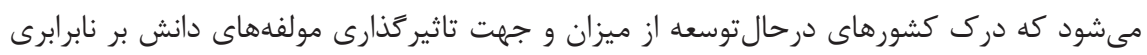

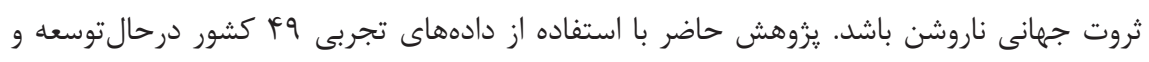

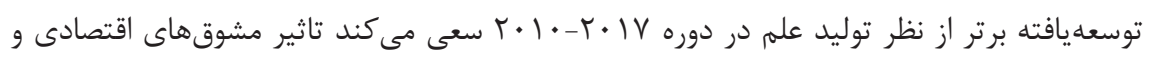

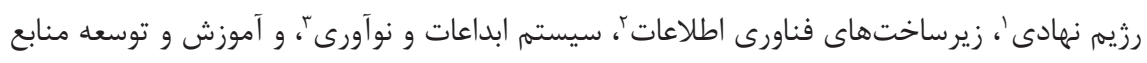

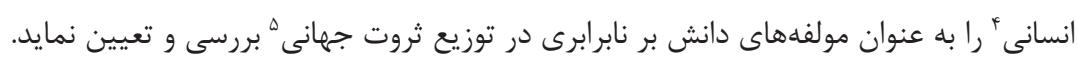

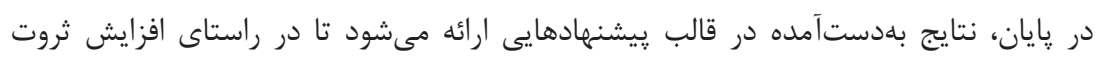
كشورهاى درحالتوسعه و كاهش نابرابرى در توزيع ثروت در جامعه جهانى مثمرثمر واقع شود.

\section{مبانى نظرى يزووهش}

در اقتصاد، برابرى برداشتى است كه شرايط اقتصادى مردم در آن همسان تلقى مىشود.

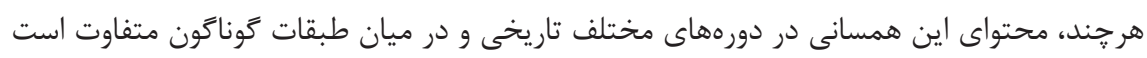

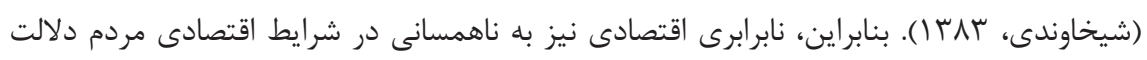

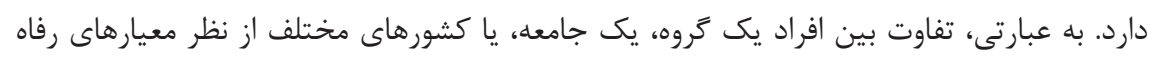
اقتصادى مانند ثروت، درآمد، و مصرف را نابرابرى اقتصادى مى گويند (Cowell \& Flachaire, 2007).

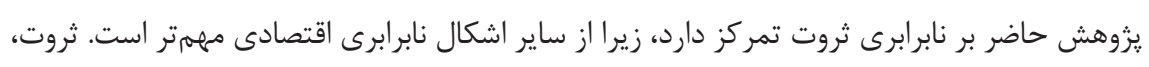

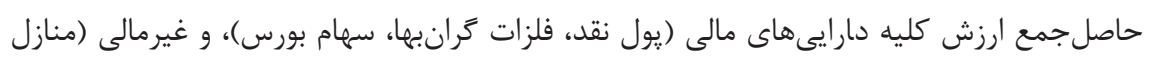

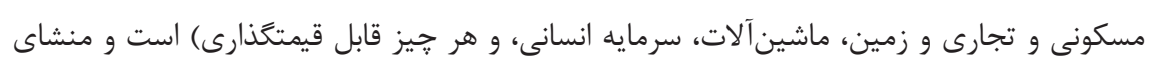
ايجاد در آمد و مصرف محسوب ميى شود.

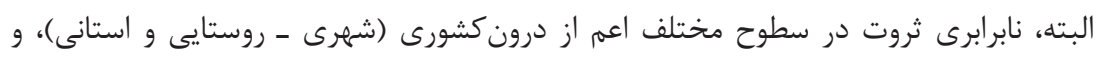

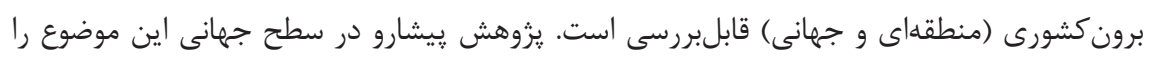

1. Economic Incentive and Institutional Regime

2. Information and Communication Technology Infrastructure

3. Innovation System

4. Education and Human Resources

5. Global Wealth Inequality 
بررسى مى كند كه از يرسشهاى محورى علم اقتصاد ـ بهويزه اقتصاد توسعه ـ محسوب مى شود. زيرا،

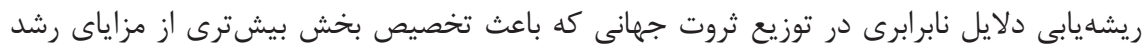

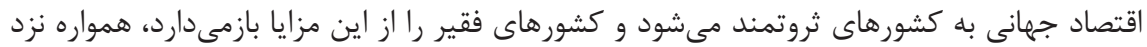

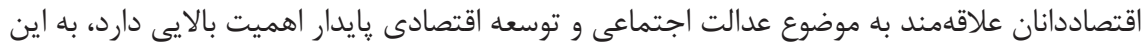

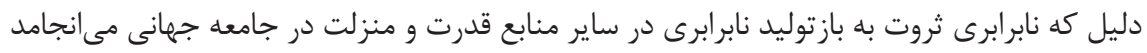

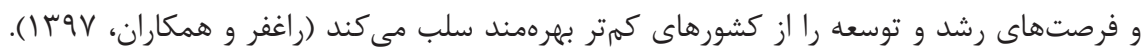

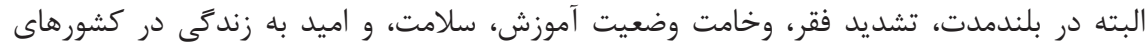

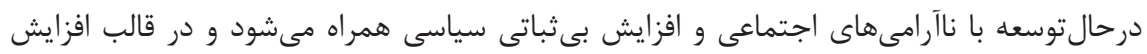

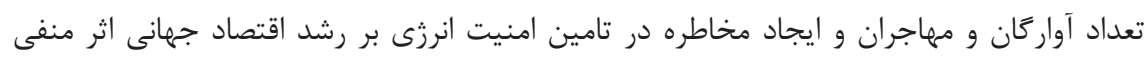

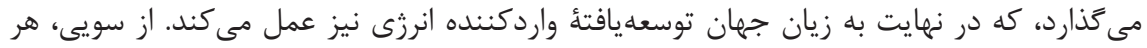

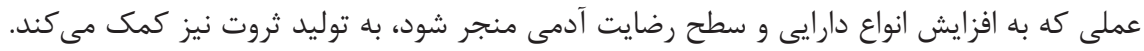

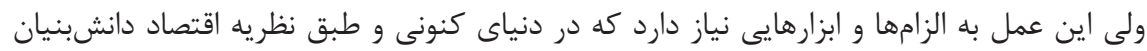

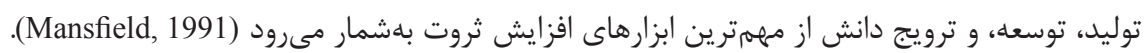

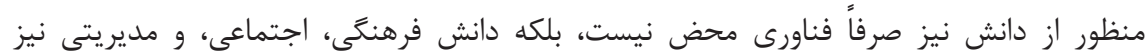

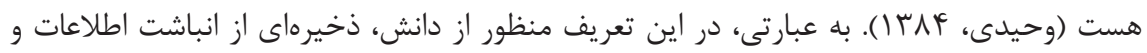
مهارتهاست كه از مصرف اطلاعات توسط كيرنده اطلاعات حاصل مىشود (Zack, 1999)، و به به عنوان

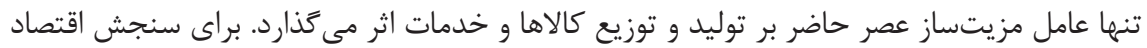

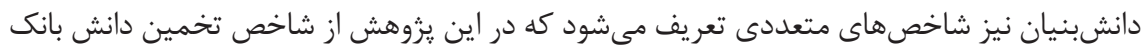

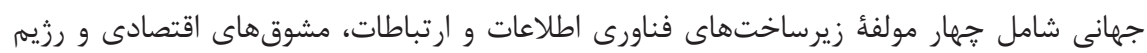

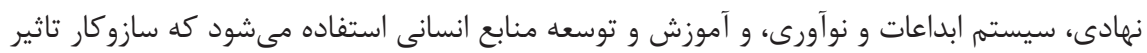

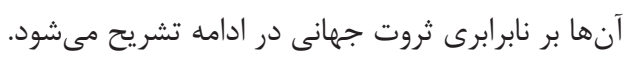

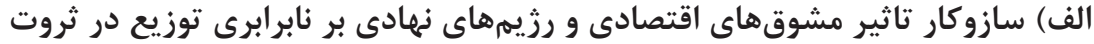

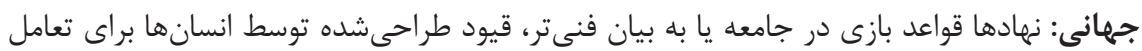

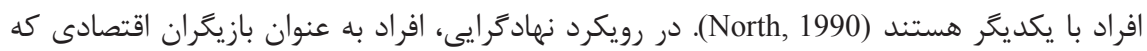

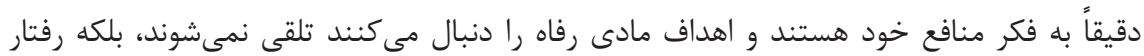

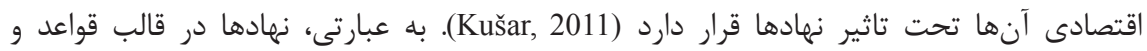

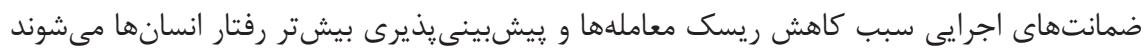


(North, 1990). بنابراين، وجود نهادهاى حقوقى، اجتماعى، و اقتصادى فراگير و بهبود كيفيت آنها با

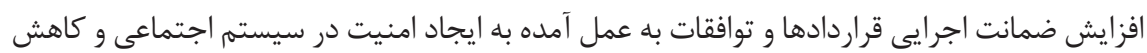
هزينه مبادله منجر مىشود. در جنين حالتى، قيمت تمامشده كالاها و خدمات توليدى كاهش و و توان رقابت آنها در بازارهاى داخلى و بينالمللى افزايش ميى يابد، و به رشد صادرات، افزايش اشتغال، و و

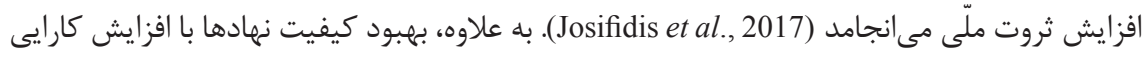

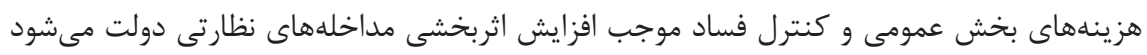

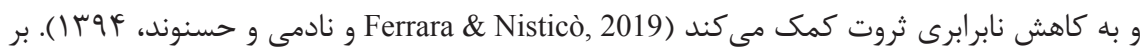

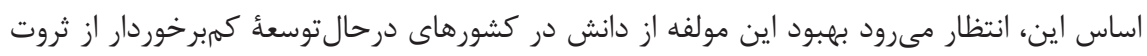

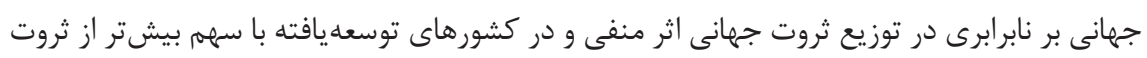

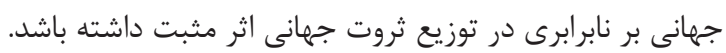

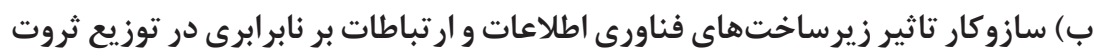

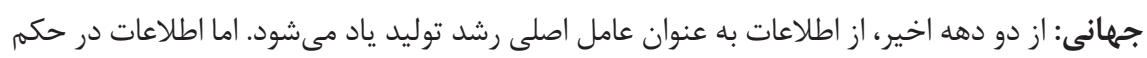
ماده اوليه است و كاربرد آن مستلزم توسعهُ فناورى اطلاعات و ارتباطات است. فناورى اطلاعات نيز

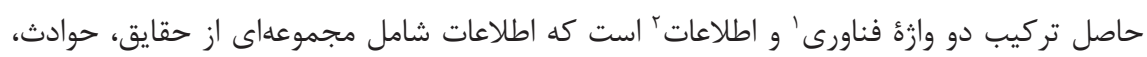

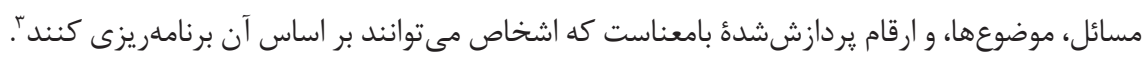

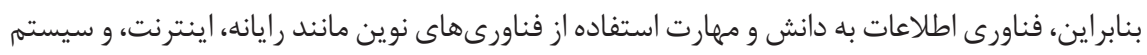
ارتباط از راه دور براى ضبط، ذخيرهسازى، يردازش، بازيابى، انتقال، و دريافت اطلاعات اشاره دارد.

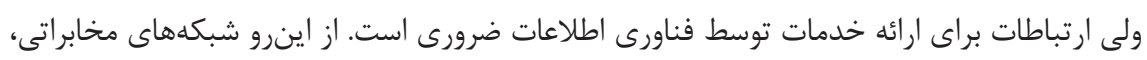
سيستمهاى راديويى اطلاعاتى و صوتى و تصويرى سيار، شبكههاى كابلى و سيستمهاى ماهوارهاى،

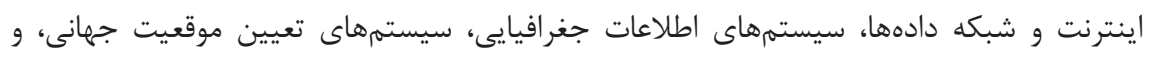

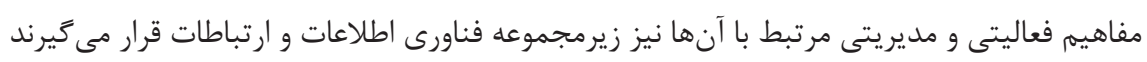

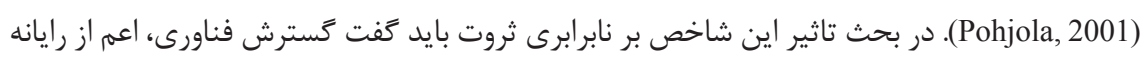

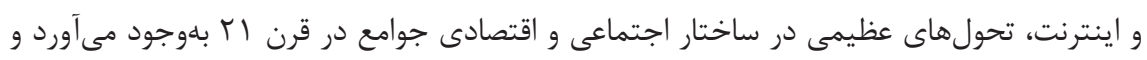

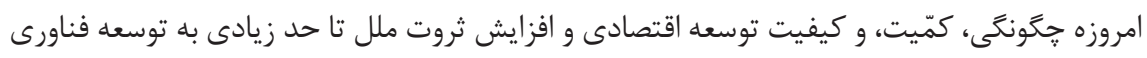

1. Technology

2. Information

r. بين اطلاعات و داده (Data) تفاوت وجود دارد. داده شامل حقايق و ارقام خام و يردازشنشده است كه براى كاربر بىمعناست. 
اطلاعات و ارتباطات و حوزههايى نظير دولت الكترونيك، بانكدارى الكترونيك، و تجارت الكترونيك بستخى دارد. زيرا در عصر اطلاعاتمحور، توليد علم باعث دانايى مىشود كه مقدمهساز توسعه فناورى است و افزايش توليد، كاهش هزينههاى توليد و بهاى تمامشده محصولات، افزايش فروش، و رشد

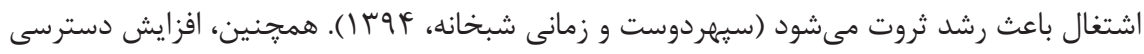

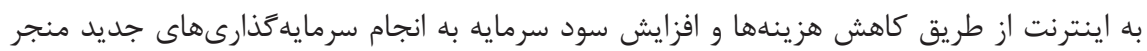
مىشود و با ايجاد رونق اقتصادى به افزايش ثروت ملّى كمك مى منمايد (Meschi \& Vivarelli, 2009).

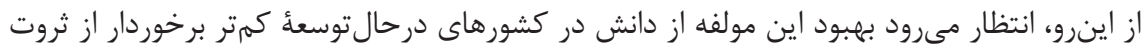
جهانى به كاهش و در كشورهاى توسعهيافتهٔ داراى سهم بيشتر از ثروت جهانى به تشديد نابرابرى در توزيع ثروت جهانى منجر شود. ״) سازوكار تاثير سيستم ابداعات و نوآورى بر نابرابرى توزيع در ثروت جهود جهانى: وازه نوآورى به تغييرهاى اساسى يا جزئى در طرز تفكر، اشيا، فرايندها يا خدمات اشاره دارد (شاهآبادى لوى لورئ

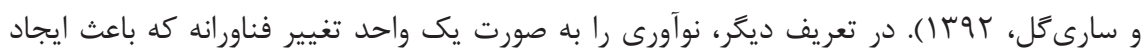
محصول، خدمت يا روش جديد مىشود، تعريف مى كنند. برخى معتقدند نوآورى همان اختراع همراه بهرهبردارى است. به عبارتى، نوآورى تنها خلاقيت نيست، بلكه عرضئ اختراع حاصل از خلاقيت به مديه

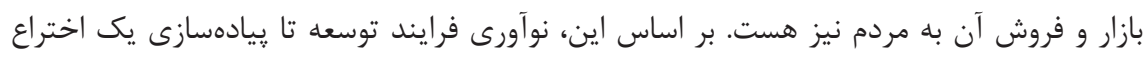

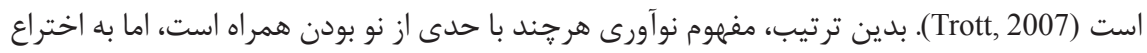

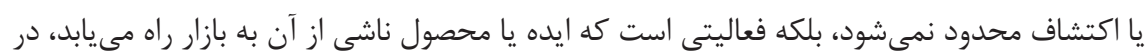

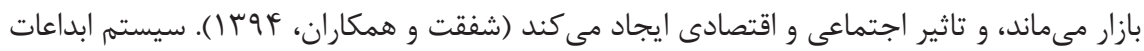

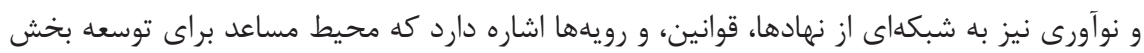

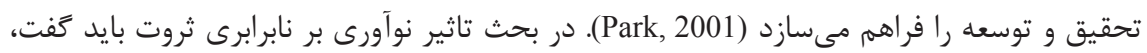

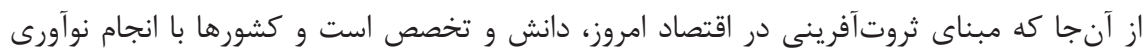

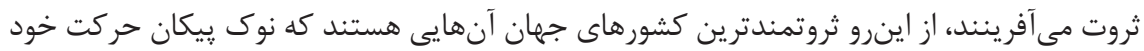

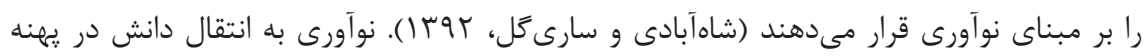

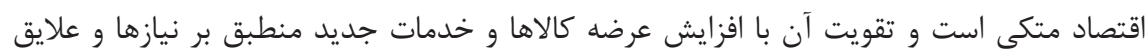
مصرفكنندًان، كاهش ريسك توسعه بازار و توسعه محصول، افزايش سود كسبو كارها، كاهش

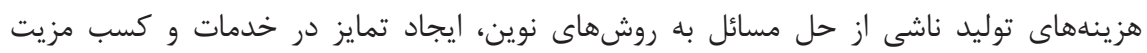

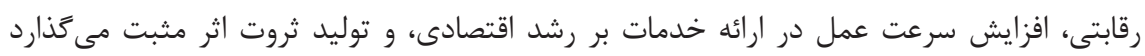


(Aghion et al., 2019). بر اساس اين، انتظار مىرود بهبود اين مولفه از دانش در كشورهاى درحالتوسعؤ كمتر برخوردار از ثروت جهانى به كاهش نابر ابرى در توزيع ثروت جهانى، و در كشورهاى توسعهيافتهٔ داراى سهم بيشتر از ثروت جهانى به تشديد نابرابرى در توزيع ثروت جهانى بيانجامد.

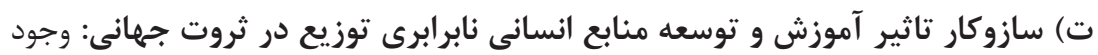
افراد ماهر و با تحصيلات بالا براى خلق، اكتساب، انتشار، و استفاده كارامد از دانش به منظور افزايش

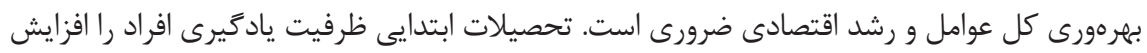

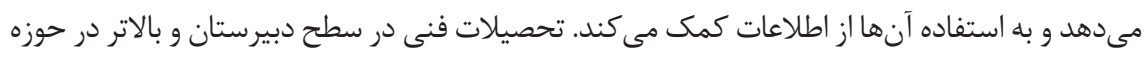

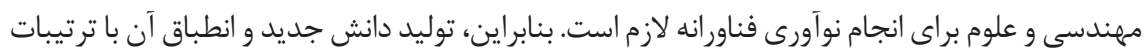

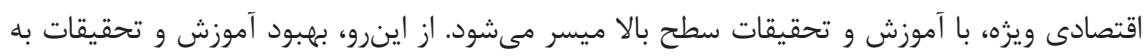

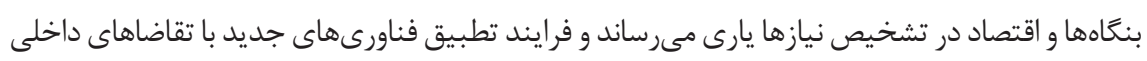
را تسهيل مى كند و نوآورى و طراحى محصولات جديد را منطبق با فرهنَ كشورها افزايش مى دهند

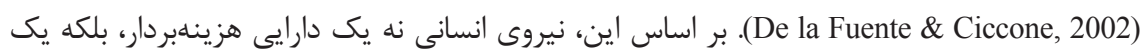

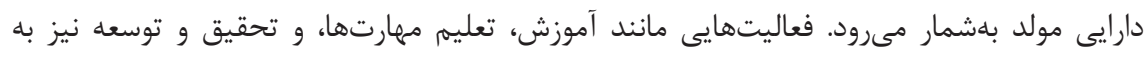

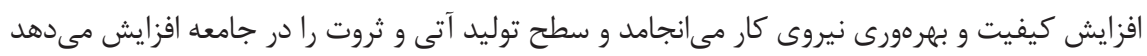
(Ningsih \& Choi, 2018)

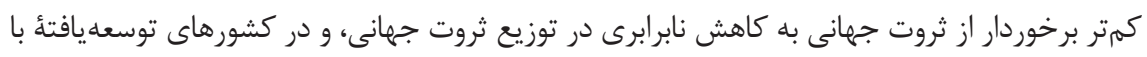

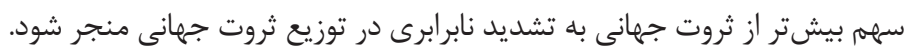

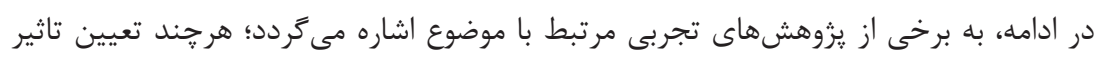

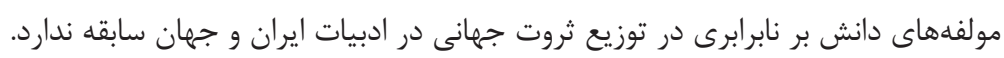

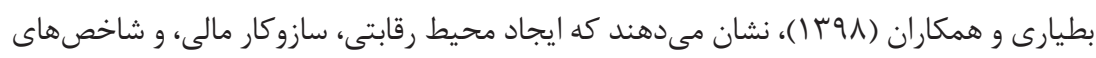

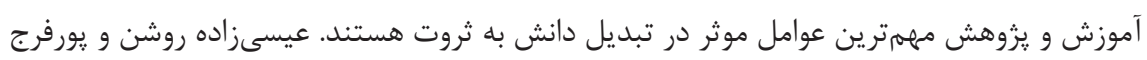

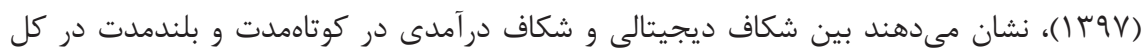

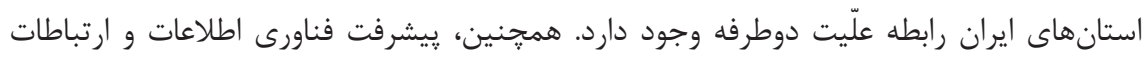

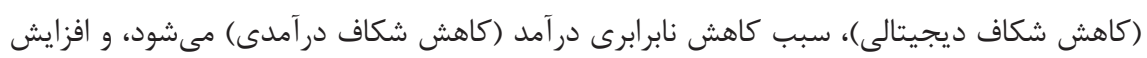

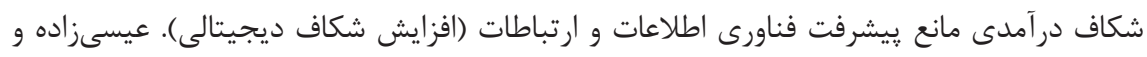

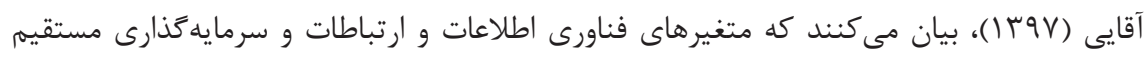
خارجى بر نابرابرى درآمد كشورها اثر منفى و معنادارى دارند. همجنين، ميزان اثر منفى فناورى إنى 
اطلاعات و ارتباطات و سرمايهَذارى خارجى بر نابر ابرى در آمد در كشورهايى با مخارج فناورى اطلاعات و ارتباطات بالا از كشورهايى با فناورى اطلاعات و ارتباطات متوسط بيشتر است. به علاوه، فناورى درى

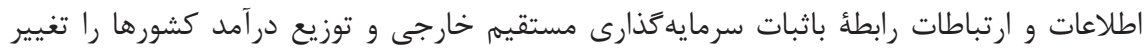

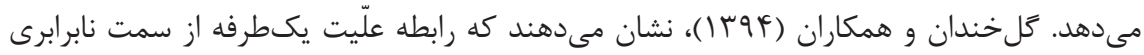
در آمد به تمام شاخصهاى فناورى اطلاعات وجود دارد. به عبارتى، نابرابرى درآمد در ايران به افزايش

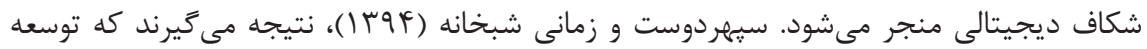

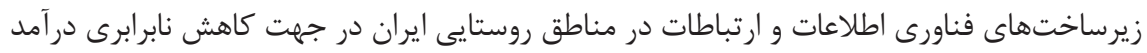

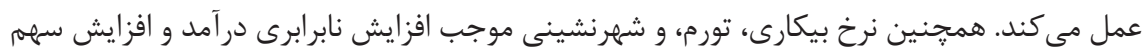
بخش كشاورزى از توليد ناخالص داخلى موجب كاهش نابرابرى درآمد در جوامع روستايى مى مى نورد.

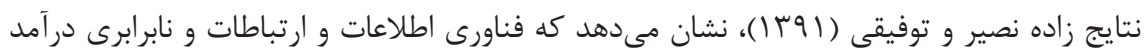

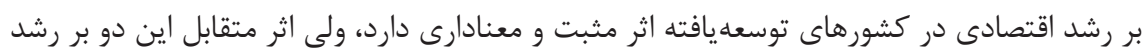

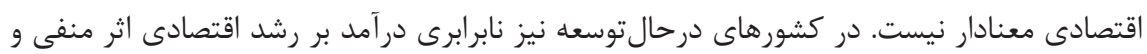
معنادارى دارد، ولى فناورى اطلاعات و ارتباطات بر رشد اقتصادى اين كشورها اثر معنادارى ندارد.

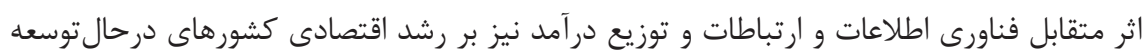

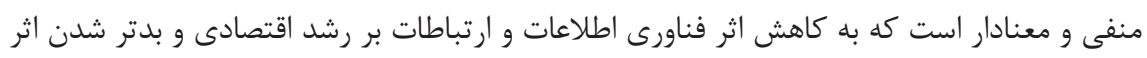

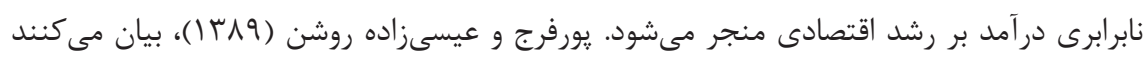
كه اثر دسترسى و زيرساخت فناورى اطلاعات و ارتباطات بر رشد اقتصادى در كشورهايى بردئ با نابرابرى

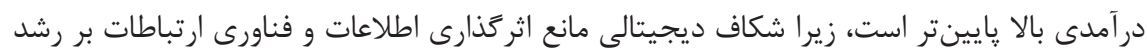

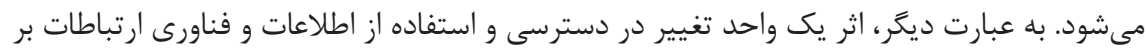

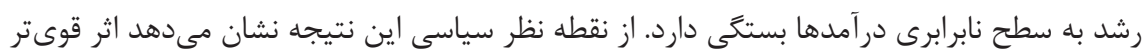

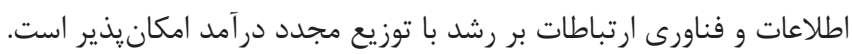

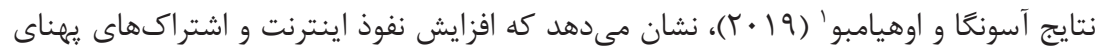
باند ثابت اثر منفى و معنادارى بر ضريب جينى و شاخص اتكينسون بـ دارد. در حالى كه افزايش نفود

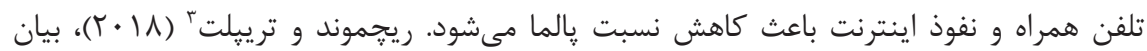

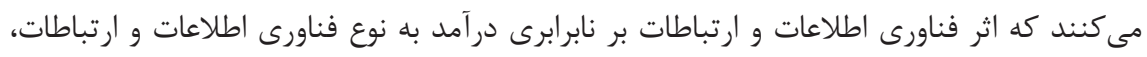

1. Asongu \& Odhiambo

2. Atkinson Index

3. Richmond \& Triplett 
روش اندازمكيرى نابرابرى درآمد، و ويزگكىهاى اقتصادى و سياسى خاص هر كشور بستخى دارد.

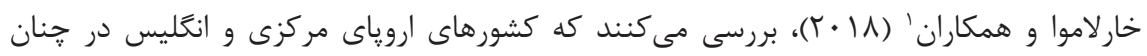

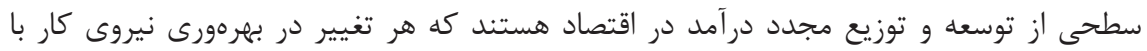

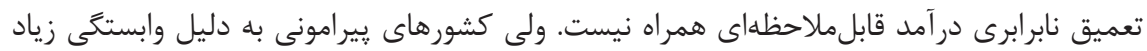

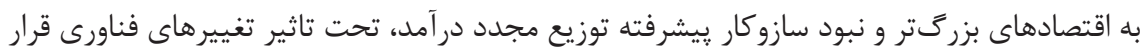

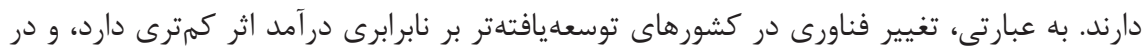

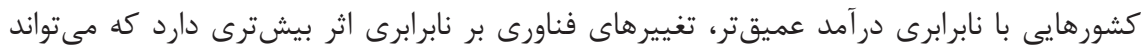

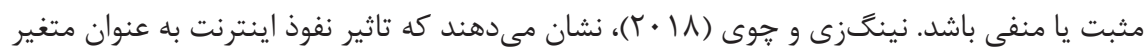

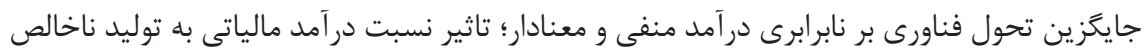

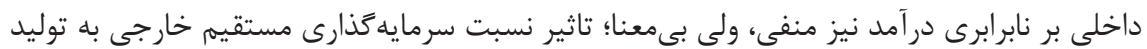

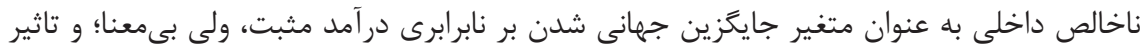

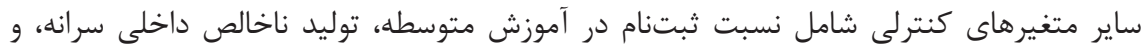

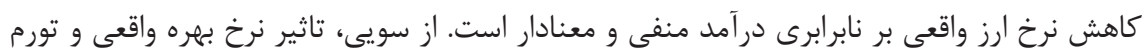

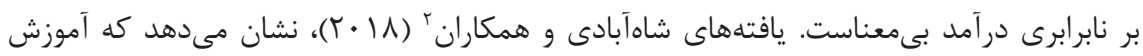

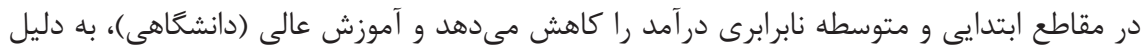

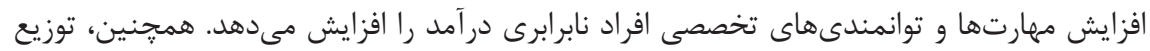

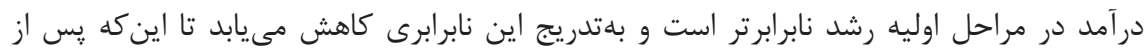

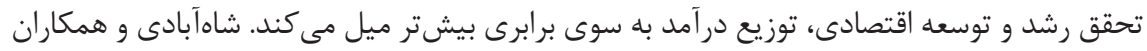

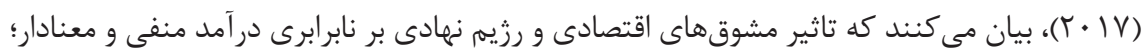

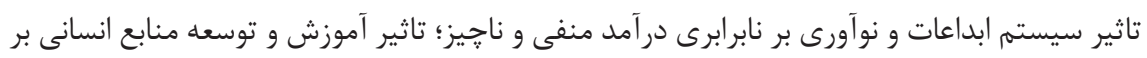

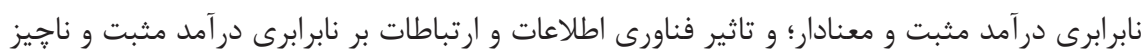

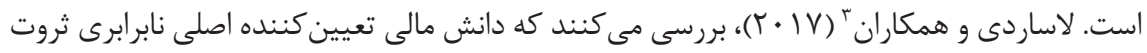

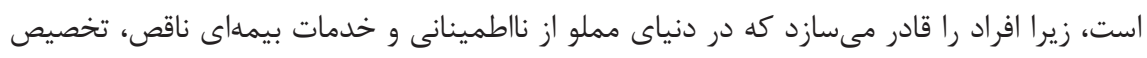

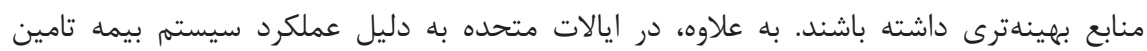

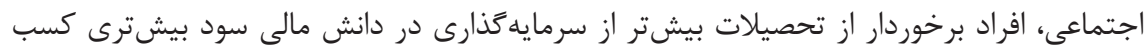

\section{Kharlamova et al.}




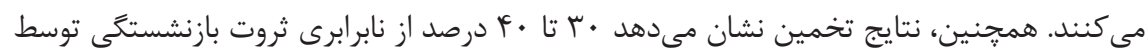

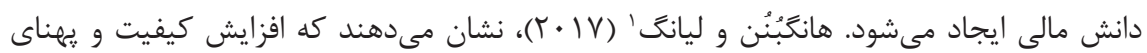

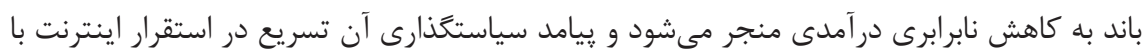

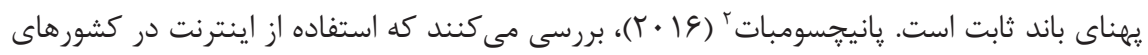
توسعهيافته نسبت به كشورهاى درحالتوسعه با كاهش بيشتر در شاخص جينى (نابرابرى كمتر)

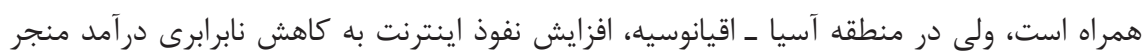

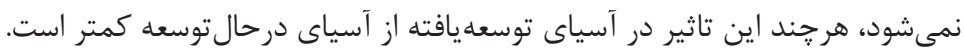

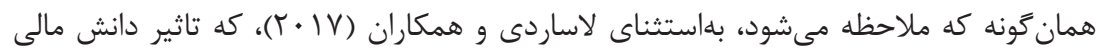

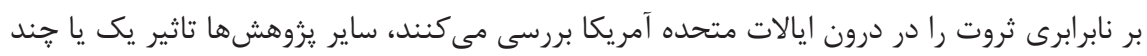

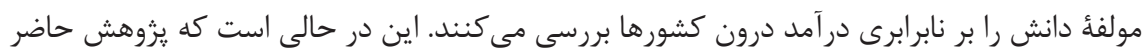

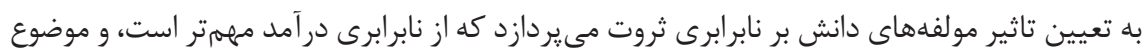
را نه در سطح كشورى، بلكه در سطح جهانى مورد بررسى قرار مى دهد.

\section{مدل يزوهش}

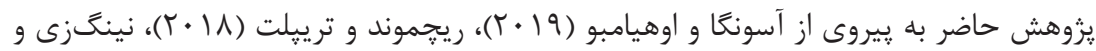

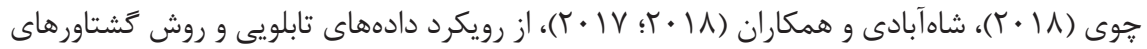
تعميميافته براى برآورد تاثير مولفههاى دانش بر نابرابرى ثروت جهانى در كشورهاى منتخب استفاده مى كند. مدل يروهش نيز به شكل لماريتمى و به صورت رابطه ( (1) است: $\log \left(\mathrm{GWI}_{\mathrm{it}}\right)=\beta_{0}+\beta_{1} \log \left(\mathrm{GWI}_{\mathrm{it}-1}\right)+\beta_{2} \log \left(\mathrm{EIIR}_{\mathrm{it}}\right)+\beta_{3} \log \left(\mathrm{ICT}_{\mathrm{it}}\right)+\beta_{4} \log \left(\mathrm{IS}_{\mathrm{it}}\right)$ (1) $+\beta_{5} \log \left(\mathrm{EHR}_{\mathrm{it}}\right)+\beta_{6} \log \left(\mathrm{GLOB}_{\mathrm{it}}\right)+\mathrm{U}_{\mathrm{it}}$

در رابطه (1)، t معرف زمان، i معرف كشورهاى عضو منتخب، و GWI نابرابرى ثروت جهانى و متغير وابسته يروهش است. GWI نابرابرى ثروت جهانى در يك سال قبل است (متغير وابسته باوقفه)، كه به عنوان متغير توضيحى در سمت راست معادله ظاهر مى شود. همجنين، اثرهاى ثابت كشورى (عرض از مبداهاى ويزه هر مقطع)، و ULit جمله خطاست. EIIR، ICT، IS، و و EHR بلترتيب نماد مولفهاى دانش يعنى مشوقهاى اقتصادى و رزيمهاى نهادى، زيرساختهاى 
فناورى اطلاعات و ارتباطات، سيستم ابداعات و نوآورى، و آموزش و توسعه منابع انسانى است، و

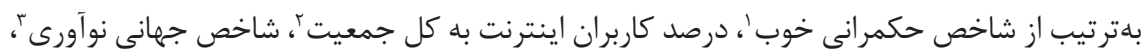

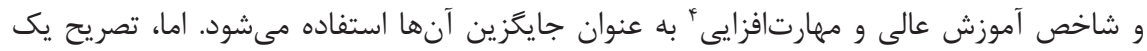
مدل اقتصادسنجى مناسب كه بتواند تغيير رفتار نابرابرى در توزيع ثروت جهانى را به نحو بيشينهاى توضيح دهد، مستلزم لحاظ نمودن ساير عوامل موثر بر آن تحت عنوان متغيرهاى كنترل است، كه در

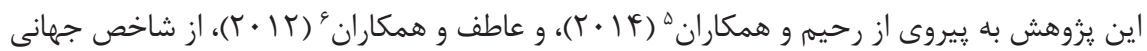
شدن (GLOB) و ابعاد آن براى اين منظور استفاده مىشود كه ميىتواند بر نابرابرى در توزيع ثروت

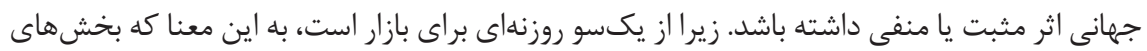

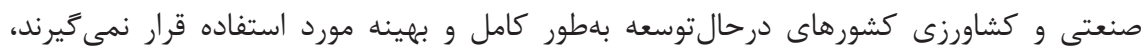
״س با گسترش رابطه اجتماعى، اقتصادى، و سياسى اين كشورها با جامعه جهانى، آنها مى توانند

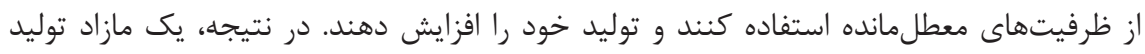
ايجاد مىشود كه با صادرات آن، ثروت آنها افزايش مى يابد و موجب كاهش نابرابرى در توزيع ثروت جهانى مىشود. به علاوه، افزايش درجه جهانى شدن از طريق توسعه بازار و تقسيم كار باعث استفاده

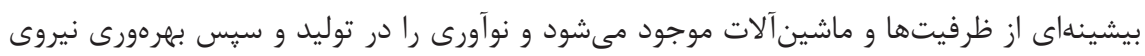

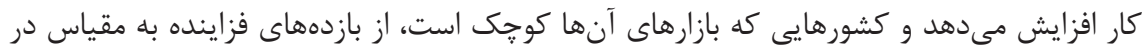

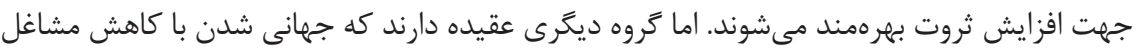
در برخى از كشورها موجب كاهش توليد داخلى و افزايش نابرابرى در توزيع ثروت جهانى مى گردد، همجنين وابستخى به جامعه جهانى فرصت بهرهكشى از كشورهاى ييرامونى را ايجاد مى كند و باعث

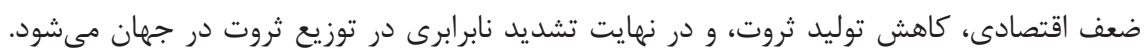

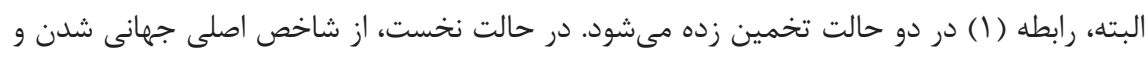

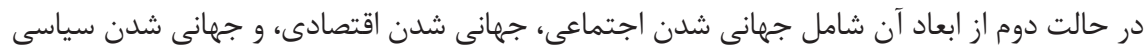

1. Good Governance

2. Individuals Using the Internet (\% of population)

3. Global Innovation Index

4. Higher Education and Training

5. Rahim et al.

7. Globalization 


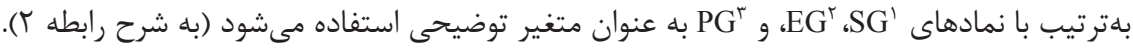
$\log \left(\mathrm{GWI}_{\mathrm{it}}\right)=\beta_{0}+\beta_{1} \log \left(\mathrm{GWI}_{\mathrm{it}-1}\right)+\beta_{2} \log \left(\mathrm{EIIR}_{\mathrm{it}}\right)+\beta_{3} \log \left(\mathrm{ICT}_{\mathrm{it}}\right)+\beta_{4} \log \left(\mathrm{IS}_{\mathrm{it}}\right)$ $+\beta_{5} \log \left(\mathrm{EHR}_{\mathrm{it}}\right)++\beta_{6} \log \left(\mathrm{SG}_{\mathrm{it}}\right)+\beta_{7} \log \left(\mathrm{EG}_{\mathrm{it}}\right)+\beta_{8} \log \left(\mathrm{PG}_{\mathrm{it}}\right)+\mathrm{U}_{\mathrm{it}}(\mathrm{T})$

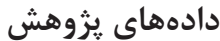

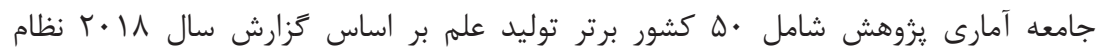

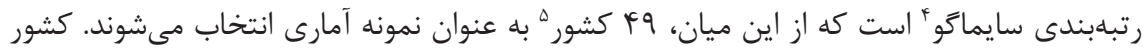
تايوان به علت نبود دادههاى مورد نياز به روش سيستماتيك حذف ميىشود. در ضمن، دادهاى

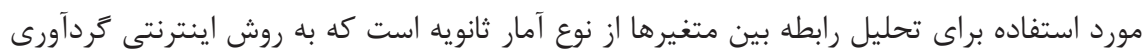

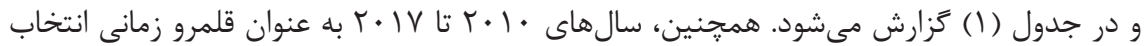

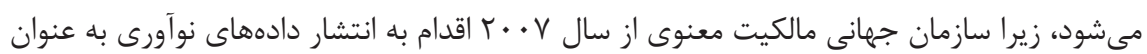
يكى از مولفههاى دانش مى كند و در سه سال ابتدايى كشور ايران را يوشش نمى دهد. به علاوه، آمار متغيرهاى حكمرانى خوب و ابعاد مختلف جهانى شدن براى سال IV IV به بعد هنوز منتشر نشده است. از اينرو، قلمرو زمانى به اين سال محدود مى شعود.

\section{Social Globalization}

2. Economic Globalization

3. Political Globalization

4. https://www.scimagojr.com/countryrank.php

ه. آرزانتين، آفريقاى جنوبى، آلمان، آمر يكا، اتريش، اسيانيا، استراليا، اندونزى، انغلستان، اوكراين، ايتاليا، ايران،

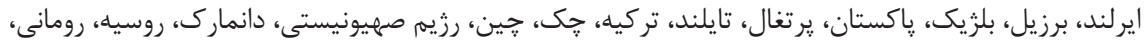
زإين، سنكايور، سوئد، سوييس، شيلى، عربستان سعودى، فرانسه، فنلاند، كانادا، كره جنوبى، كلمبيا، لهستان، مالزى، مجارستان، مصر، مكزيك، نروز، نيجريه، نيوزلند، هلند، هند، هنگَكنَ، ويتنام، و يونان. 
جدول ا: منابع آمارى متغيرهاى بيزوهش

\begin{tabular}{|c|c|c|c|}
\hline نشانى اينترنتى & يايعاه آمارى & نام متغير & نوع متغير \\
\hline https://www.credit-suisse.com & موسسه مالى كرديت & ن ابرابرى ثروت جهانى & وابسته \\
\hline www.worldbank.org & بانك جهانى & زيرساختهاى فناورى اطلاعات & \\
\hline www.govindicators.org & شاخص حكمرانى خوب & مشوقهاى اقتصادى و رزيم & 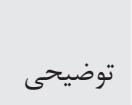 \\
\hline $\begin{array}{l}\text { www.wipo.int/portal/en/index } \\
\text { https://reports.weforum.org/ } \\
\text { global-competitiveness-report }\end{array}$ & $\begin{array}{l}\text { سازمان جهانى مالكيت معنوى } \\
\text { مجمع جهانى اقتصاد }\end{array}$ & آموزش و توسعه منابع انسانى ابداعات و نوآورى & \\
\hline $\begin{array}{l}\text { https://kof.ethz.ch/en/ } \\
\text { forecasts-and-indicators }\end{array}$ & موسسه تحقيقات در زمينه & 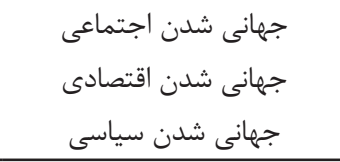 & 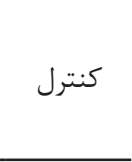 \\
\hline
\end{tabular}

\section{تخمين مدل}

روشهاى معمول اقتصادسنجى بر فرض ايستايى متغيرها استوار است و استفاده از دادهاى ع آن

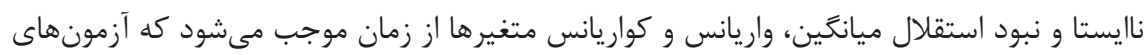
T، F از تخمين مدل بايد ايستايى متغيرها بررسى شود، ولى در اين يزوهش به علت طول كمتر از

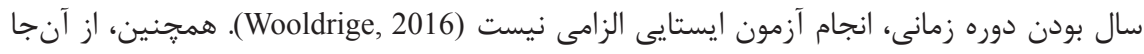

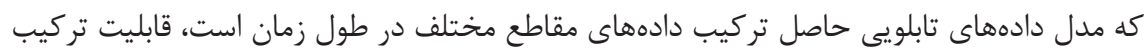

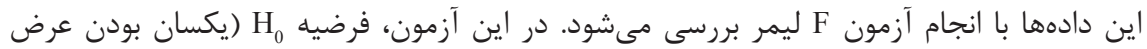
از مبداها) در مقابل فرضيه H1 (متفاوت بودن عرض از مبداها) مورد بررسى قرار مى كيرد. نتايج به

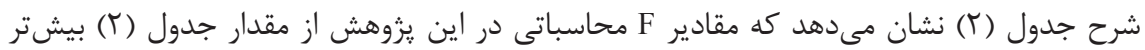

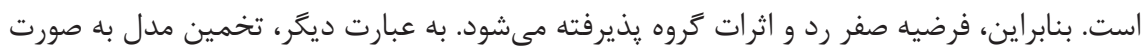
دادههاى تابلويى تاييد مىشود. 
جدول r: نتايج آزمون قابليت تخمين مدل به صورت دادههاى تابلويى

\begin{tabular}{|c|c|c|c|}
\hline حالت ل & آماره F & احتمال & نتيجه \\
\hline اول اول & $19 / \pi 90$ & $\cdot \%$ & مدل به صورت دادههاى تابلويى \\
\hline 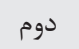 & $\mid Q / 1 F \Delta$ & $\cdot / \cdot$ & مدل به صورت دادههاى تابلويى \\
\hline
\end{tabular}

در نهايت، با توجه به اين كه در مدل دادههاى تابلويى يويا به واسطه اضافه شدن متغير وابستهٔ

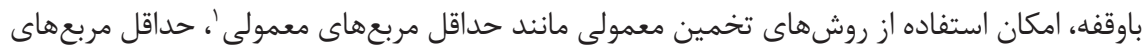

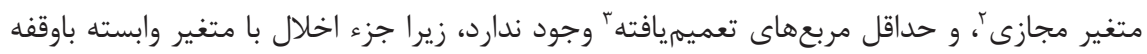
همبستكى ييدا مى كند و نتايج تخمين دجار تورش مى مىشود، به همين دليل از روش گشتاورهاى

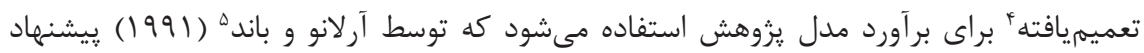
مىشود و ضمن رفع مشكل همبستكى متغير مستقل با جزء اخلال، درونزايى متغيرها و ناهمسانى واريانس مدل را نيز رفع مى كند. اين تخمينزن در هر دو حالت اثرات ثابت و تصادفى كارايى دارد و

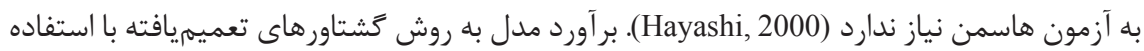

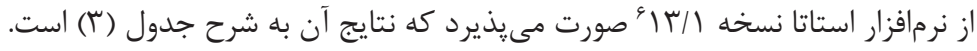

1. Ordinary Least Squares

2. Last Squares Dummy Variable

3. Generalized Least Squares

4. Generalized Method of Moments

5. Arellano \& Bond

6. Stata 13.1 
جدول r: نتايج بر آورد مدل يثوهش به روش عشتاورهاى تعميميافته

\begin{tabular}{|c|c|c|c|c|}
\hline متغير وابسته: نابرابرى ثروت جهانى & \multicolumn{2}{|c|}{ حالت اول } & \multicolumn{2}{|c|}{ حالت دوم } \\
\hline متغيرهاى توضيحى & ضريب & 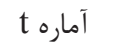 & 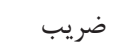 & آماره t \\
\hline L GWI (-1) & $\cdot 11 \cdot r *$ & $\Delta / 99 V$ & $\cdot 11 \cdot \Delta *$ & $\Delta / \mathbb{C} \Delta T$ \\
\hline L EIIR & $-\cdot 1 \cdot \Delta \omega *$ & $-\downarrow / \wedge 9 \wedge$ & $-\cdot / \cdot \Delta F_{*}$ & $-\Delta / \wedge q \uparrow$ \\
\hline L ICT & $-\cdot|\cdot r|$ **⿻丷木 & $-r / 1 / \Delta$ & $-\cdot \mid \cdot r r_{*} *{ }^{*}$ & זr/ז- \\
\hline L IS & $\cdot / \cdot \wedge V_{*}$ & $0 / 99 r$ & $\cdot / \cdot \wedge \vee * *$ & D/बq \\
\hline L EHR & .1 .91 䊉 & r/TGF & $\cdot 1 \cdot 9 \cdot$ * *** & ז/几 \\
\hline L GLOB & $\cdot 1 \cdot$ fr & 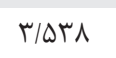 & - & - \\
\hline L SG & - & - & $\cdot / \cdot \Delta F$ & 1/9rT \\
\hline L EG & - & - & $\cdot / \cdot \Lambda \mathrm{r} * * *$ & r/Gr. \\
\hline L PG & - & - & $\cdot 1 \cdot 48$ & $1 / 9 \vee 9$ \\
\hline Sargan test statistic & G/VGr & $\cdot|\Delta| \Delta$ & $9 / 99 \vee$ & $\left.\cdot|\Delta|\right|^{\mathrm{C}}$ \\
\hline AR(1) & $-\mu / T \Delta$ & $\cdot 1 \cdots$ & $-r / \mu$ & $\cdot 1 \cdot \cdots$ \\
\hline $\operatorname{AR}(2)$ & $-\cdot 149$ & $.19 \mathrm{VV}$ & $-\cdot / T F$ & $\cdot|9 \Delta|$ \\
\hline $\mathrm{R}^{2}$ & & & & \\
\hline A. $\mathrm{R}^{2}$ & & & & \\
\hline Number of obs & & & & \\
\hline Number of groups & & & & \\
\hline Obs per group & & & & \\
\hline
\end{tabular}

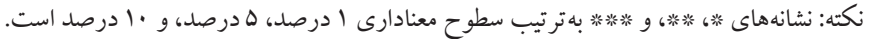

درباره مندرجات جدول (r) بايد گَفت، به منظور اطمينان از مناسب بودن روش گشتاورهاى

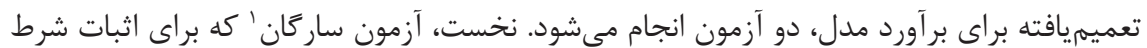
اعتبار تشخيص بيش از حد، يعنى اعتبار صحت متغيرهاى ابزارى بكار مىرود و فرضيه صفر آن دال

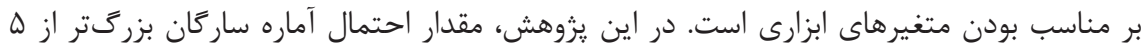

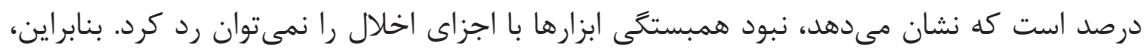

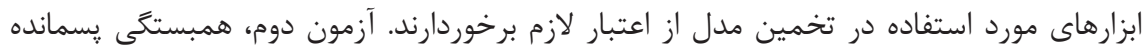


مرتبه اول (1) و مرتبه دوم AR(2) است كه به زعم آرلانو و باند (1991)، در تخمين گشتاورهاى

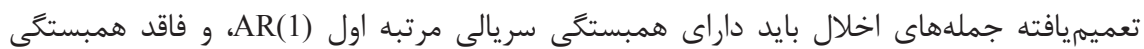
سريالى مرتبه دوم AR(2) باشند. نتايج اين آزمون نشان مى دهد كه ضريب خودركرسيونى مرتبه اول AR(1) معنادار و ضريب خودر گرسيونى مرتبه دوم AR(2) بىمعناست. بنابراين، در تخمين مدل يروهش تورش تصريح وجود ندارد و نتايج قابلاطمينان است. به علاوه، براى بررسى ميزان همخوانى مردي دادهاى تجربى و مدل مفهومى، نيكويى برازش مدل ارزيابى مى شود و نتايج نشان مى دهد تعديلشده نزديك به ا است كه به معناى نيكويى مدل برازشيى شده است.

\section{بحث و نتيجه}

يروهش حاضر با هدف تعيين تاثير مولفههاى دانش شامل مشوقهاى اقتصادى و رزيم نهادى، زيرساختهاى فناورى اطلاعات، سيستم ابداعات و نوآورى، و آموزش و توسعه منابع انسانى بر نابرابرى توزيع ثروت جهانى در كشورهاى منتخب درحالتوسعه و توسعهيافته توليد كننده علم در دوره V I • r• 1 • ا انجام مى شود. نتايج نشان مىدهد كه مشوقهاى اقتصادى و رزيم نهادى كشورهاى منتخب بر نابرابرى ثروت

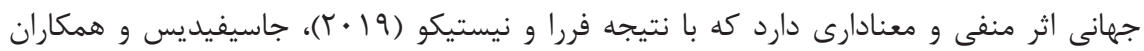

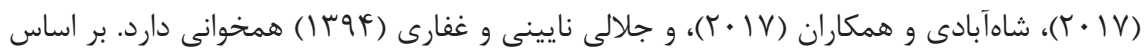
اين، 1 درصد بهبود در مشوقهاى اقتصادى و رزيم نهادى در كشورهاى منتخب در حالات اول و

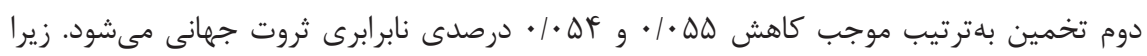

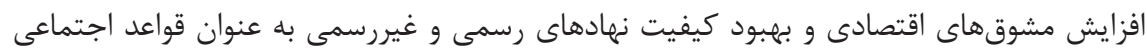
تثبيتشده با افزايش اثربخشى دولت و كاهش فساد و رانتجويى به شكل ميرى روابط اجتماعى و و اقتصادى عادلانهتر و تخصيص بهينهتر منابع در جامعه جهانى كمك مى كند و زمينه رشد اقتصادى و افزايش ثروت ملل را فراهم مىسازد. به علاوه، از طريق افزايش اثربخشى دولتها و كاهش فساد

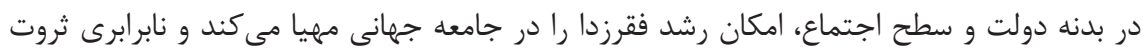
جهانى را كاهش مى دهد. تاثير درصد خانوارهاى داراى اينترنت كشورهاى منتخب بر نابر ابرى ثروت جهانى منفى و معنادار

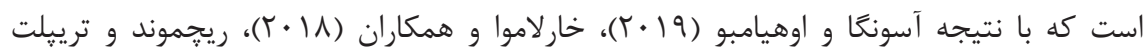

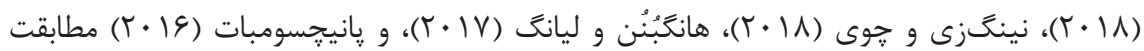




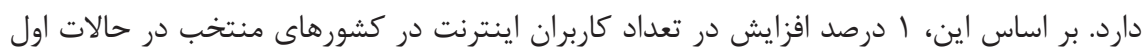

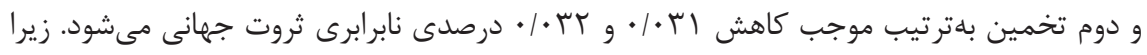

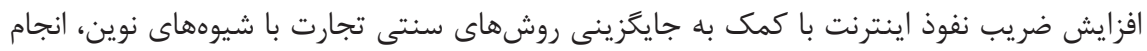

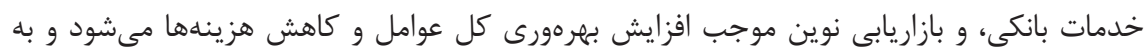

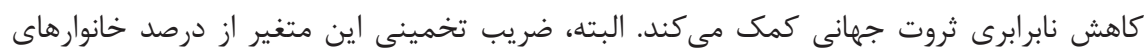

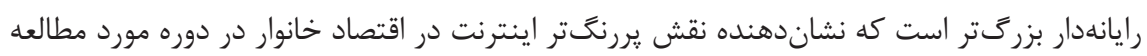

تاثير سيستم ابداعات و نوآورى در كشورهاى منتخب بر نابرابرى ثروت جهانى مثبت و معنادار

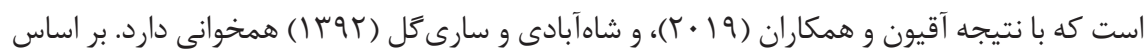

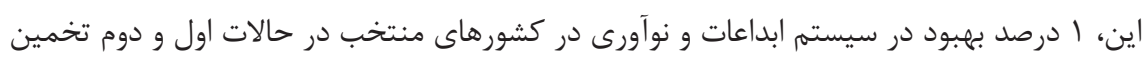

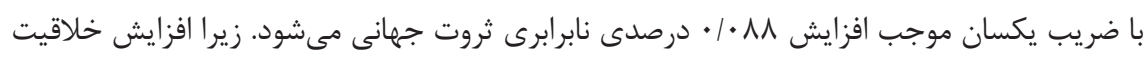

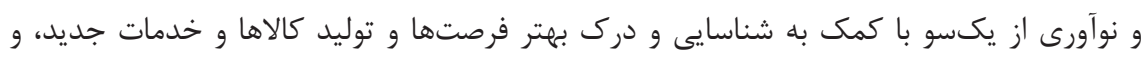

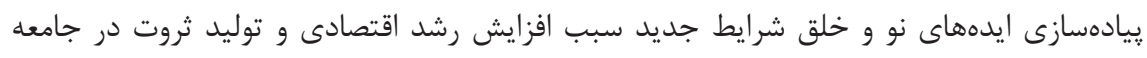

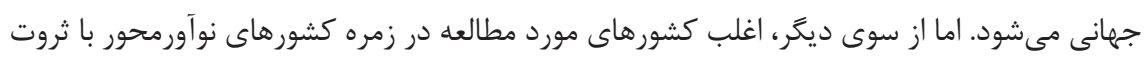

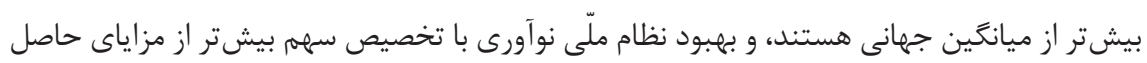

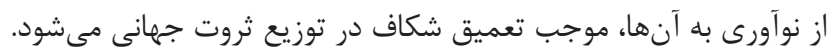

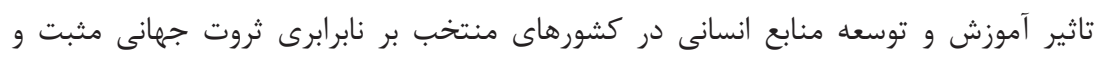

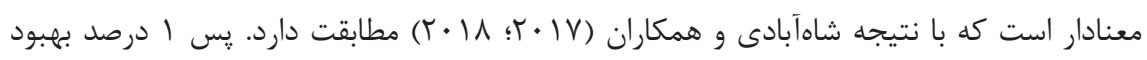

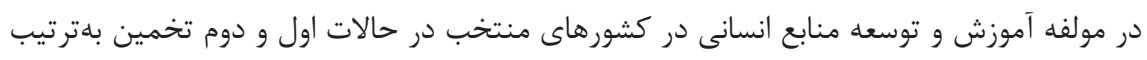

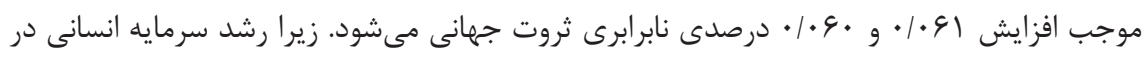

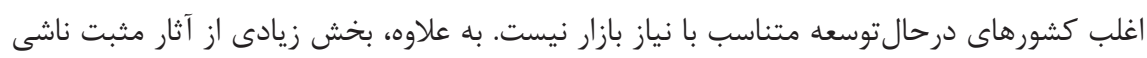

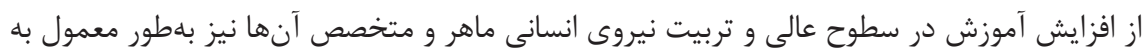

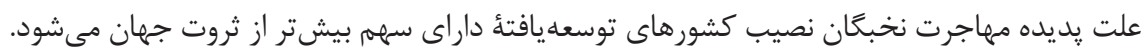

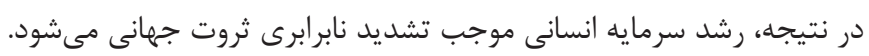

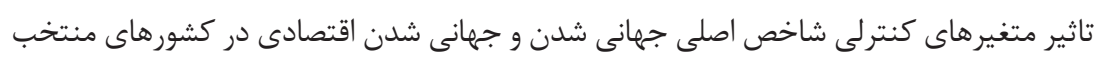

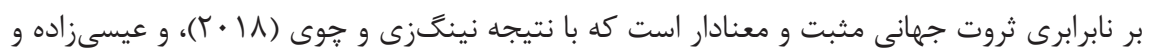

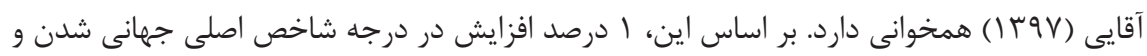


جهانى شدن اقتصادى در كشورهاى منتخب موجب افزايش Tr • • • و r • • • درصدى نابرابرى ثروت

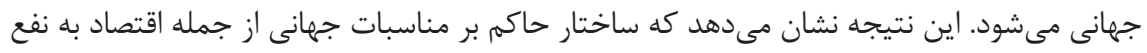
كشورهايى با سهم بيشتر از ثروت جهانى و به زيان كشورهايى با سهم كمتر از ثروت جهانى در جريان

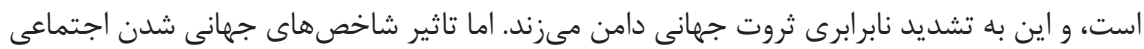
و جهانى شدن سياسى در كشورهاى منتخب بر نابرابرى ثروت جهانى مثبت ولى فاقد معنادارى آمارى است. تاثير متغير وابسته باوقفه (نابرابرى ثروت جهانى در يك سال قبل)، در كشورهاى منتخب بر مبرى

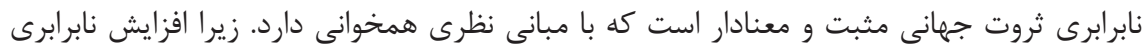
ثروت جهانى در سال قبل، از وجود بستر و ساختار لازم براى اين كار حكايت دارد و تسرى اين شرئ شرايط

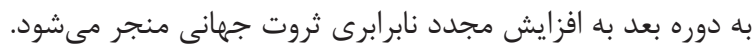

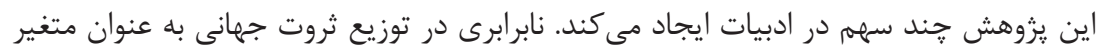

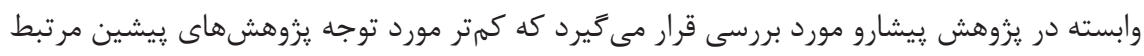

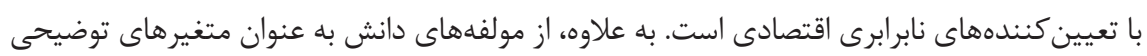

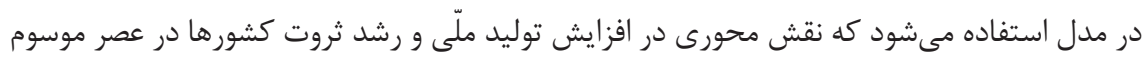

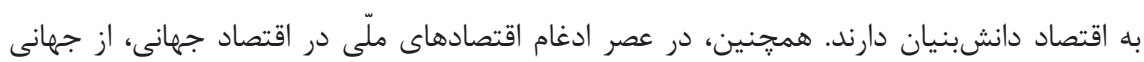
شدن اقتصادى، جهانى شدن اجتماعى، و جهانى شدن سياسى به عنوان متغيرهاى كنترل در مدل

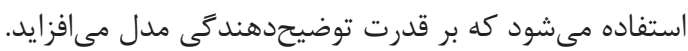

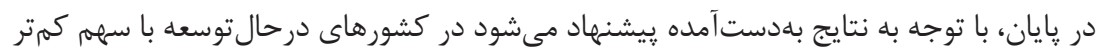

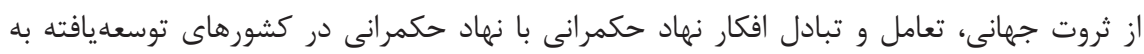
منظور بهره

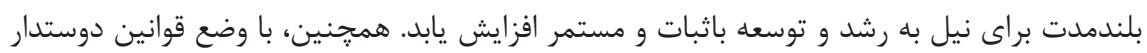
سرمايه، افزايش اثربخشى دولت و كنترل فساد، زمينه تشكيل نهادهاى فراگير مورد نياز براى دستيابى رشد اقتصادى فقرزدا مهيا شود. به علاوه، با توسعه زيرساختهاى مخابراتى و الكترونيكى و دسترسى

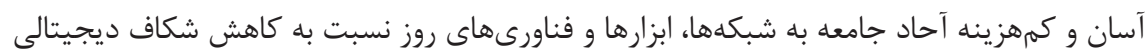

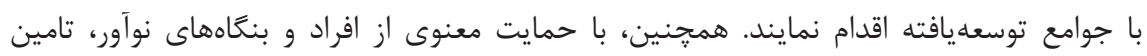

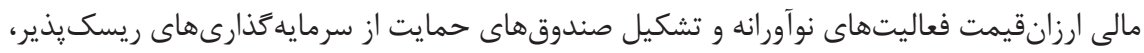

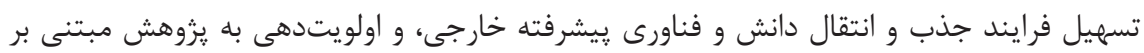

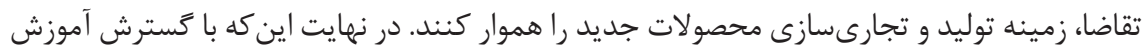


عمومى و افزايش سطح سواد همعانى، و ايجاد رشتههاى دانشخاهى مرتبط با نياز بازار، شايستهسالارى

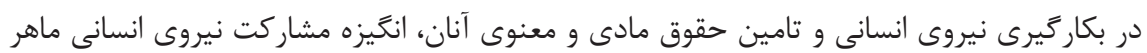

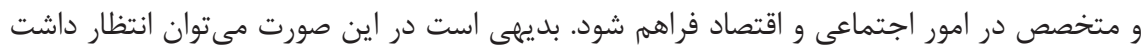

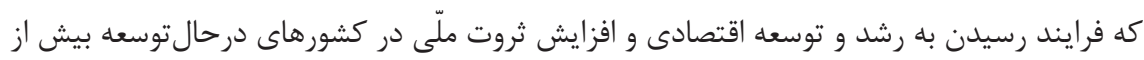
يميش فراهم شود و نابرابرى در توزيع ثروت جهانى كاهش يیدا كند.

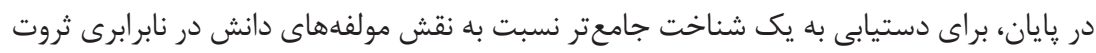

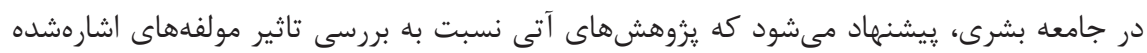

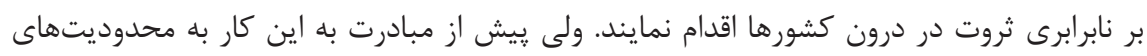

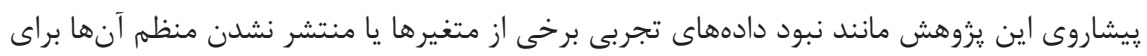

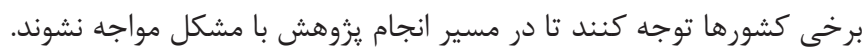

\section{منابع}

$$
\text { الف) فارسى }
$$

بطيارى، اعظم؛ نياز آذرى، كيومرث، و جبارى، نَين (191 (1). شناسايى عوامل موثر تبديل دانش به ثروت از ديد

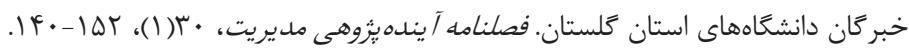

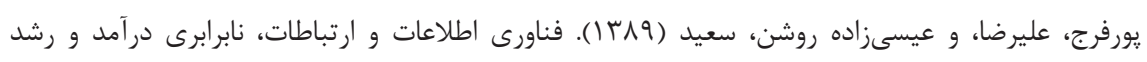

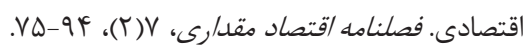

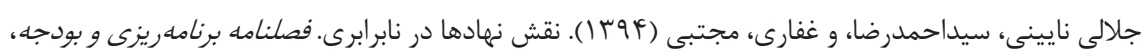
.

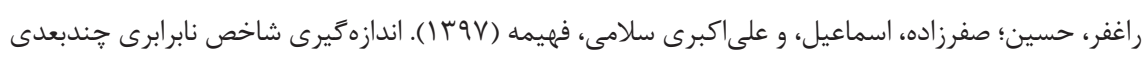

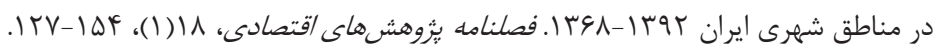

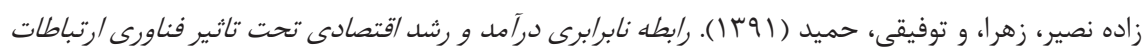

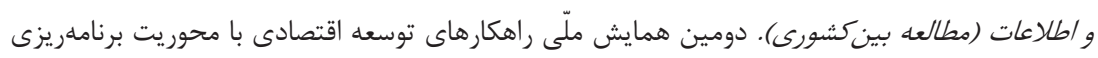
منطقهاى. سيهردوست، حميد، و زمانى شبخانه، صابر (1M9Y). تاثير فناورى اطلاعات و ارتباطات بر شكاف درآمدى

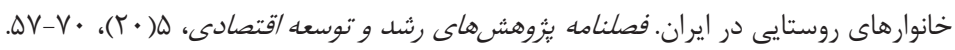
شاهآبادى، ابوالفضل، و سارى 


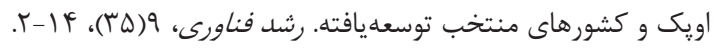

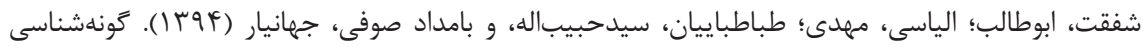

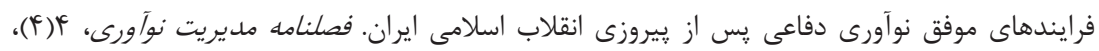

$.1 M-1 \Delta F$

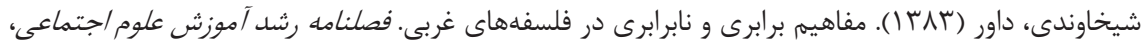

$$
\begin{aligned}
& \text { ( } 4 \text { - }
\end{aligned}
$$

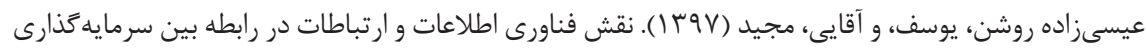

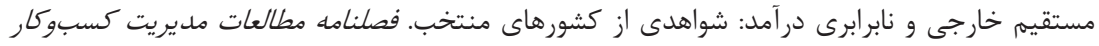

$$
\begin{aligned}
& \text { هوشمنل، } 9 \text { (T) }
\end{aligned}
$$

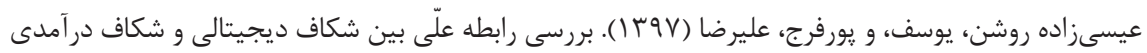

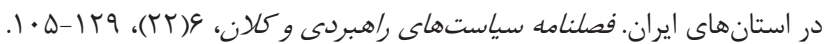

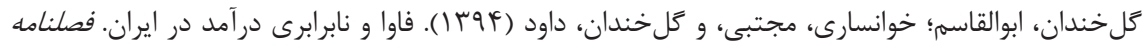

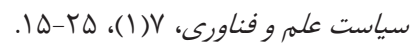

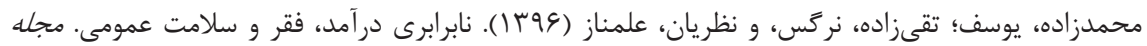

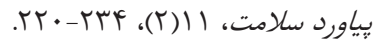

$$
\begin{aligned}
& \text { نادمى، يونس، و حسنوند، داريوش (Y (1). اثرات آستانهاى اندازه دولت بر نابرابرى توزيع درآمد در ايران. }
\end{aligned}
$$

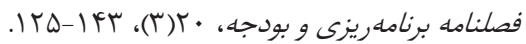

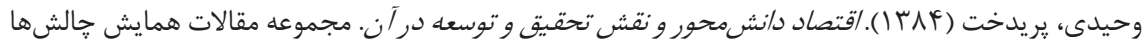

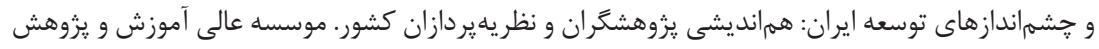

$$
\begin{aligned}
& \text { مديريت و برنامهريزى. }
\end{aligned}
$$

Aghion, P., Akcigit, U., Bergeaud, A., Blundell, R., \& Hémous, D. (2019). Innovation and Top Income Inequality. The Review of Economic Studies, 86(1), 1-45.

Arellano, M., \& Bond, S. (1991). Some Tests of Specification for Panel Data: Monte Carlo Evidence and an Application to Employment Equations. The Review of Economic Studies, 58(2), 277-297.

Asongu, S. A., \& Odhiambo, N. M. (2019). How Enhancing Information and Communication Technology Has Affected Inequality in Africa for Sustainable Development: An Empirical Investigation. Sustainable Development, 27(4), 647-656.

Atif, S. M., Srivastav, M., Sauytbekova, M., \& Arachchige, U. K. (2012). Globalization and Income Inequality: A Panel Data Analysis of 68 Countries. ZBW - Deutsche Zentralbibliothek für Wirtschaftswissenschaften, Leibniz- Informationszentrum 
Wirtschaft, Kiel und Hamburg.

Cowell, F. A., \& Flachaire, E. (2007). Income Distribution and Inequality Measurement: The Problem of Extreme Values. Journal of Econometrics, 141(2), 1044-1072.

De la Fuente, A., \& Ciccone, A. (2003). Human Capital in a Global and Knowledge-Based Economy (Vol. 562): Office for Official Publications of the European Communities.

Ferrara, A. R., \& Nisticò, R. (2019). Does Institutional Quality Matter for Multidimensional Well-Being Inequalities? Insights from Italy. Social Indicators Research, 145(3), 1063-1105. Hayashi, F. (2000). Econometrics. Princeton University Press.

Houngbonon, G. V. \& Liang, J. (2017). Broadband Internet and Income Inequality. HAL Id: hal-01653815, https://hal.archives-ouvertes.fr/hal-01653815.

Josifidis, K., Supić, N., \& Beker-Pucar, E. (2017). Institutional Quality and Income Inequality in the Advanced Countries. Panoeconomicus, 64(2), 169-188.

Kharlamova, G., Stavytskyy, A., \& Zarotiadis, G. (2018). The Impact of Technological Changes on Income Inequality: The EU States Case Study. Journal of International Studies, 11(2)-76-94.

Kušar, S. (2011). The Institutional Approach in Economic Geography: An Applicative View. Croatian Geographical Bulletin, 73(1), 39-49.

Lusardi, A., Michaud, P.-C., \& Mitchell, O. S. (2017). Optimal Financial Knowledge and Wealth Inequality. Journal of Political Economy, 125(2), 431-477.

Mansfield, E. (1991). Academic Research and Industrial Innovation. Research Policy, 20(1), 1-12.

Meschi, E., \& Vivarelli, M. (2009). Trade and Income Inequality in Developing Countries. World Development, 37(2), 287-302.

Ningsih, C., \& Choi, Y.-J. (2018). An Effect of Internet Penetration on Income Inequality in Southeast Asian Countries. The 22nd Biennial Conference of the International Telecommunications Society: "Beyond the Boundaries: Challenges for Business, Policy and Society", June 24th - 27th, 2018, Seoul, Korea.

North, D. (1990). Institutions, Institutional Change and Economic Performance: Cambridge University Press.

Panichsombat, R. (2016). Impact of Internet Penetration on Income Inequality in Developing Asia: An Econometric Analysis. ASR: CMU Journal of Social Sciences and Humanities, 3(2), 151-167.

Park, S. O. (2001). Regional Innovation Strategies in the Knowledge-Based Economy. GeoJournal, 53(1), 29-38.

Pohjola, M. (2001). Information Technology, Productivity, and Economic Growth: International Evidence and Implications for Economic Development: Oxford University Press.

Rahim, H. L., Abidin, Z. Z., Ping, S. D. S., Alias, M. K., \& Muhamad, A. I. (2014). Globalization and Its Effect on World Poverty and Inequality. Global Journal of Management and Business, 1(2), 8-13.

Richmond, K., \& Triplett, R. E. (2018). ICT and Income Inequality: A Cross-national Perspective. International Review of Applied Economics, 32(2), 195-214.

Shahabadi, A., Nemati, M., \& Hosseinidoust, S. E. (2017). The Effect of Knowledge Economy Factors on Income Inequality in the Selected Islamic Countries. Journal of the 
Knowledge Economy, 8(4), 1174-1188.

Shahabadi, A., Nemati, M., \& Hosseinidoust, S. E. (2018). The Effect of Education on Income Inequality in Selected Islamic Countries. International Journal of Asia-Pacific Studies, 14(2)-61-78.

Trott, P. (2007). The Management of Technology and Innovation: A Strategic Approach. Edited by Margaret White and Garry Bruton. R\&D Management, 37(4), 379-380 .

Wooldridge, J. M. (2016). Introductory Econometrics: A Modern Approach: Nelson Education.

Zack, M. H. (1999). Developing a Knowledge Strategy. California Management Review, 41(3), 125-145. 